\title{
Erythema Infectiosum
}

National Cancer Institute

\section{Source}

National Cancer Institute. Enythema Infectiosum. NCI Thesaurus. Code C84695.

A self-limited viral infectious disorder caused by the human parvovirus B19. It affects predominantly children and is characterized by the development of a bright red skin eruption in the cheeks. It is followed by a maculopapular skin eruption in the extremities which eventually fades into a lacey pattern. 